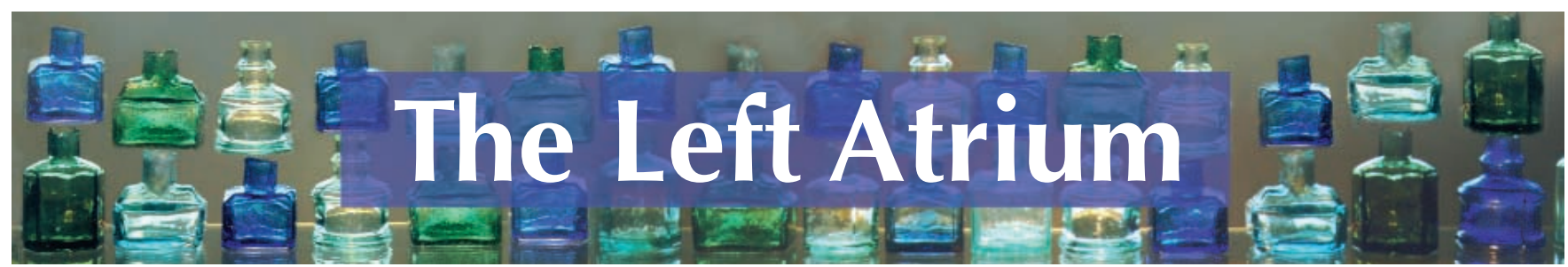

\section{The ties that bind}

Les Triplettes de Belleville/The Triplets of Belleville

Directed by Sylvain Chomet

Columbia Tristar, 2003, 81 min

Les Invasions barbares/The Barbarian Invasions

Directed by Denys Arcand

Alliance Atlantis, 2003, $112 \mathrm{~min}$

La Grande séduction/Seducing Doctor Lewis

Directed by Jean-François Pouliot

Alliance Atlantis, 2003, $109 \mathrm{~min}$

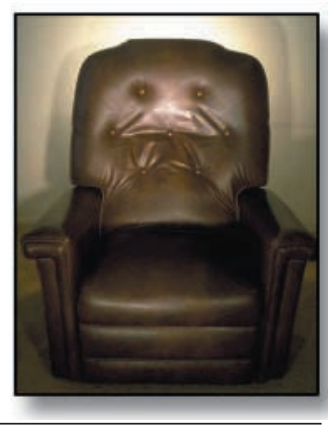

$\mathrm{T}$ hese three Canadian co-productions have won many international awards (Cannes, Sundance, Hollywood Grammys) and have affirmed the Canadian imagination as fertile ground to attract audiences throughout the world.

The Triplets of Belleville, a French/ Canadian/Belgian collaboration, is an adult-rated animation directed by Sylvain Chomet. It was ten years in the planning and five in the execution, with most of the work done in the Montréal studio. In the story, Champion, adopted by his clubfooted grandmother Mme Souza after a tragic accident (implied by a photo of his father and mother on a bicycle on his bedroom wall) is a very sad child. $\mathrm{He}$ comes to life, however, after his grandmother gives him a tricycle. As her grandson grows, Mme Souza supervises a rigorous training schedule, and both of their lives revolve around getting Champion ready for the Tour de France.

During the event the French Mafia kidnap the guileless Champion and two other cyclists. As they are whisked away in a transatlantic oceanliner, Mme Souza and the faithful family dog Bruno (blessed with a telepathic sense of smell) follow them in a pedal-boat to Belleville (an amalgam of Paris, New York and Montréal, according to Chomet). Champion and the other cyclists are sequestered in a secret building. Destitute, Bruno and Mme Souza are taken under the wing of the zany Belleville Triplets, three quirky sexagenerian sisters who were cabaret stars in their prime. Their diet consists mostly of some variation of frog meat (soup, skewers and lollipops). Together they hatch a plot to find and save Champion.

The animation is mostly handdrawn; in the filmmaker's view, the not match the quality of original rendering. The story is delivered withoutdialogue, tapping the universal potential of imagery. The stylized characters and Gothic backgrounds convey emotional and aesthetic qualities not possible in films with either flesh-and-blood actors or computer-generated graphics. In terms of plot, content and theme, Champion's mindless obedience to his abductors and the film's numerous references to Franco-American relations and our consumerist society are facile interpretations that the film transcends by transporting us to fertile imaginary landscape where anything is possible.

In Les Invasions barbares, writer and filmmaker Denys Arcand has created a successful sequel to Le Déclin de l'empire américain (The Decline of the American Empire, 1987). The main character, Rémy, a washed-up academic who spent most of his adult life chasing women and having affairs, is stricken with terminal cancer and has little time left. His ex-wife calls their son Sébastien, a successful options trader in London, to comfort his father in his last days. Sébastien, who takes a dim view of his father, grudgingly accepts. To please his mother he tries to procure for his father all the comforts money can buy by bribing and cajoling various hospital officials (obtaining a priquality of computer graphics still does vate room on a floor closed down by budget cuts). Sébastien also calls up Rémy's friends and mistresses from the past (all characters from The Decline of the American Empire) to share his dying moments. They engage in witty intellectual banter about all the "isms" of the 70s, how they view their legacy and how society has changed. The film is at its best in this comedic vein, wrapped by the tragic overtones of Rémy's demise.

The film's counterweight is the antiheroine Nathalie, the daughter of one of Rémy's mistresses, a pretty junkie called into service to soothe Rémy's pain. As opposed to the support lavished on Rémy by his other friends and family, Nathalie holds up a mirror to his questions about whether he did the best he could as a father, a university professor and a responsible member of a privileged society. Rémy is helped into a "soft death" by a heroin overdose at his friend's cottage, forgiven by his son, admired by his exwife and surrounded by his friends. Before he dies he briefly wakes up from his heroin-induced coma, sees Sébastien, and mumbles "The barbarians are coming."

Although the film is a meditation on seeking out what is important in life, what I enjoyed most is Arcand's audacity in tackling the barbarian invasions: the forces that besiege us internally and externally and how we react to them. Nathalie the addict and Sébastien with his cash are clearly identified as the children of the intellectual elite of the baby-boomer generation. This is the "legacy question": what do we value in life, how will we pass it on, and how will history judge us? Not easy stuff to pull off in a film. Critics of the film, such as Jean Larose in Le Devoir (May 2003), have questioned the happy ending, arguing that Arcand has let his characters off too easily; Rémy has regrets but no conscience, and he is still allowed to die peacefully and forgiven.

In Seducing Doctor Lewis (La Grande séduction) Ste-Marie-la-Mauderne is an isolated island village on the north shore of Quebec whose main industry, fishing, is 
no longer viable. Men drained of their pride line up like shadows to collect their unemployment cheques at the post office. The town might be able to attract a plastics manufacturing plant, but only if they can also attract a doctor (and raise a $\$ 50000$ bribe). When a hot-shot cocaine-snorting Montréal plastic surgeon is stopped for speeding and a bag of coke drops out from his wallet, he is given a sentence to serve as temporary town doctor in this outpost. The town has one month to convince this urbanite that SteMarie-la-Mauderne is the best place for him to live. All 125 townspeople, led by the mayor, engage in an elaborate seduction scheme based on anticipating Dr. Lewis's whims. They tap his private phone line and find out that he likes jazz, boeuf bourguignon and cricket. At first the doctor thinks he has landed in par-

\section{Room for a view}

\section{The salt of tears}

Some of the best memories I never Shad are of visiting my Great-Uncle Donald Ross at his home in Grafton, just a short drive from Kingston. We would pull up the tree-lined drive to the family farm, Katie still young and vital at 72 , and me, her grandson, beside her. I remember my legs sticking to the textured vinyl seats of her ' 69 Volkswagen Beetle as we bounced up the potholed drive. Once we stopped I would jump out of the car, race up the steps and pound on the door. Then I would press my ear against it, listening. Sometimes I would hear Alice's soft footsteps. At other times I would hear a rhythmic thumping before the door opened. Once my Great-Uncle Donald let me hold his wooden leg and told me what happened to his real one.

Jan 2216

Mr. Donald Ross

Grafton Ontario

Dear Donald just a few lines to let you know that I think you did right adise. The mayor nearly has "his fish reeled in" but then is overcome by pangs of conscience when the young doctor discovers that his Montréal girlfriend was cheating on him and, in a drunken stupor, admits that the village is the only genuine, trustworthy thing in his life.

This charming comedy is in the vein of Waking Ned Devine and, to a certain extent, The Shipping News. It shows the ties that bind in small communities where everyone knows everyone's business and everything - suffering, triumph and joy - is shared. Economic survival linked to personal pride in a changing economy, hanging on to a certain quality of life and (similarly to Les Invasions barbares) questioning what is really important in life are recurring themes. There is a dynamic tension between portraying people as country bumpkins but also as resourceful and cunning and standing up to oppressive institutions (banks, government). The film has been criticized for what other people liked about it: a breath of fresh air for some, it is too cliché-ridden and predictable for others.

These films about our evolving Canadian culture and identity show that wellconstructed films that resonate with the public can be mirrors reflecting our collective achievments and concerns. As ironic facsimiles of Canadian reality - a jaded generation, the hardships of rural life, shortfalls in health care - these ingenious films ring true. It remains for an equivalent ingenuity to be applied to the social problems they reflect.

\section{Normand Carrey \\ Psychiatrist \\ Halifax, NS}

in joining the army and if I had a son I should want him to do as you have. Now Donald you are going to two wars the one against the Germans you will look after I know but the other one is the hardest to win the battle of life. The two things that make a good man is to keep clear in mind and clean in body and the only way to do so is to keep a clear head don't let hooch fuddle your brain always remember first you are a Canadian and a Ross and if you want to you can come home an officer. I hope you will not be offended at this old cripple who knows what you will have to go through.

Well Donald Good Luck and God speed you all join in sending love and good wishes

I am as ever

Your Uncle Caleb Mallory 238 River Avenue Winnipeg Man

\section{Dear Mother}

Here I am writing a letter which I am going to try and get somebody at some of the stations we pass to mail to you.

We left Valcartier camp about ten A.M. The country is very wild along the railway you see nothing but woods and swamp between stations it is generally quite a distance between stations. It is about 9:30 P.M. now some of the boys are asleep and a couple of my old tent mates are bothering the life out of them. Everybody is putting on a lighthearted smile although we all feel we are leaving home for some time. But everyone is cheerful and happy including myself. Tell dad I received his letter. I did not get the one I expected from you but will likely get it in Halifax before I leave. Tell Dad I will write as soon as we land. It may be a matter of weeks before I get a chance to write again so Good Bye.

Yours Lovingly

Donald

(It is mighty hard writing on the train) 